\title{
A TRAGÉDIA DA FUGA NA ENEIDA
}

\author{
Eduardo da Silva de Freitas* \\ Recebido em: 03/03/2020 \\ Aprovado em: 15/04/2020
}

$*$ Professor Adjunto
de língua e literatura
latina, Departamento
de Letras Clássicas,
Universidade Federal
do Rio de Janeiro.

eduardosfreitas@gmail.com

(D)

RESUMO: O artigo analisa a construção trágica da fuga de Eneias por Virgílio. Em primeiro lugar, aponta-se que esse não era um tema de encaixe fácil no gênero épico da Antiguidade. Depois, abordam-se algumas maneiras de tratar a tragédia na épica de Virgílio. Por fim, examina-se a fuga de Eneias no livro II da Eneida, observando sua elaboração trágica.

PALAVRAS-CHAVE: Eneida; épica; tragédia.

\section{THE TRAGEDY OF THE FLIGHT IN THE AENEID}

\begin{abstract}
The paper analyzes the tragic construction by Virgil of the flight of Aeneas. First, it points out that this was not a theme that easily fitted in ancient epic. Next, it addresses some way of treating the tragedy in the Virgilian poem. Lastly, it examines the flight of Aeneas in the second book of the Aeneid by noting his tragic elaboration.
\end{abstract}

KEYWORDS: Aeneid; epic; tragedy.

\section{INTRODUÇÃO}

$\mathrm{U}$

$m$ dos grandes desafios artísticos enfrentados por Virgílio foi tratar a fuga de Eneias como tema épico. Tradicionalmente, a fuga não faz parte do conjunto de situações passíveis de menção positiva quanto ao desempenho dos heróis. No contexto homérico, por exemplo, associada à covardia, sua invocação se presta à ofensa aos desafetos e adversários, além de servir para testar a coragem dos companheiros de batalha.

Em três cenas na Ilíada, é tida como evidente sinal de desonra para o guerreiro. No canto I da Ilíada, Agamêmnon acusa Aquiles de fugir do combate (phềge, Il., I, 173), quando o filho de Tétis ameaça deixar a guerra por causa da ofensa pública que sofre da parte do Atrida. Mais adiante, após duro revés, Agamêmnon pretende testar a 
fidelidade e a coragem da tropa no canto IX, sugerindo que os aqueus deixem a cidadela de Troia e voltem para suas casas. Na ocasião, Diomedes se sente ofendido e afirma que não deixaria o campo de batalha ainda que ficasse só (Il., IX, 45-9). Por fim, em trecho do canto $\mathrm{XX}$, que envolve o próprio herói da épica virgiliana, Aquiles zomba de Eneias no meio do duelo, porque, certa vez em que haviam se encontrado no monte Ida, Eneias fugira da luta (Il., XX, 177-98).

O contexto da épica latina é mais nebuloso. A fuga, de fato, está presente tanto no Belllum Punicum de Névio, quanto nos Annales de Ênio. Nestas obras, faz-se menção ao deslocamento dos troianos depois que os gregos conseguiram entrar na cidade. Alguns fragmentos da obra de Névio, mencionados por gramáticos antigos, falam claramente de Eneias ter deixado Troia (Blänsdorf, 2011, p. 44 e 49). Em um deles, os troianos são chamados de vigorosos, strenui viri, que certamente se trata de um elogio. Quanto a Ênio, não se pode afirmar com muita certeza sobre o valor que atribui à fuga. Os trechos tão somente apontam que os troianos haveriam de deixar Troia dirigindo-se para a Itália, onde haveriam de se estabelecer (Schönberger, 2009, p. 27-9).

O fato é que, pelos fragmentos dos poemas épicos latinos anteriores a Virgílio, é difícil formar uma imagem de como a fuga aparece nos textos. Névio, que fala dos "vigorosos varões" deixando Troia, menciona também lágrimas das mulheres de Eneias e de Anquises. Em seu poema, aparece também choro do próprio Eneias durante a partida (Blänsdorf, 2011, p. 43-4). Ênio fala da travessia pelo mar, mas não é possível dizer se o sentido que atribui a este fato é negativo ou positivo no conjunto da narrativa. De toda forma, é bem provável que em ambos os casos a fuga guardasse um teor positivo.

No entanto, deve-se notar que, nestes poemas, a fuga é apenas uma pequena ação sem maiores significados a compor o todo dessas obras. Nos dois poemas, ela se integra a uma arquitetura textual que não parece se orientar por qualquer ideia de unidade de ação. Quer dizer, no Bellum Punicum e nos Annales, a fuga não parece um elemento tão relevante para a construção da narrativa quanto o é na Eneida. O livro de Névio é uma narrativa sobre a Primeira Guerra Púnica e a obra de Ênio é um extenso apanhado da história de Roma desde seu passado lendário até a época em que o poeta vivera. Em verdade, elas apenas tangenciam o que na épica virgiliana é central.

De fato, na Eneida, a fuga está no cerne da obra, já que a ação do poema parte do deslocamento de Eneias e seus companheiros de Troia para a Itália. Isso faz com que o tratamento da fuga tenha que ser diferente. Sendo seu papel mais saliente, o poeta a incorpora de uma maneira mais complexa. Ela é elementar ao motivo da épica e ao mesmo tempo de difícil enquadramento positivo no gênero. Eneias é um profugus, termo que pode ser entendido tanto como "fugitivo", mas também como "banido", "exilado". Nesse sentido, considerando as circunstâncias do gênero e da invenção poética de Virgílio, é de se esperar que a fuga de Eneias não possa ser sinal de covardia, nem ser tratada de modo superficial, e talvez por isso a ênfase recaia mais nos últimos sentidos mencionados. A Virgílio cabia encontrar uma forma de satisfazer essas necessidades, com uma personagem de que a tradição não guardava grandes realizações heroicas. Este trabalho aborda como Virgílio representa a fuga na Eneida, 
tomando-a como tema épico. A ideia que se propõe é que o poeta alcança esse resultado, na medida em que a caracteriza tragicamente, por meio de um conjunto de representações que suscitam os sentimentos típicos do gênero consagrado na Grécia do século V a.C.

Ora, o viés trágico da épica virgiliana já era reconhecido desde a Antiguidade. Marcial chama o autor da Eneida de Maro cothurnatus, tomando metonimicamente o coturno, calçado utilizado pelas personagens nas tragédias, para designar a poesia de Virgílio. Poucos séculos depois, Macróbio reconheceria em Virgílio, ingens [...] cum Graecarum tragoediarum scriptoribus familiaritas, "enorme familiaridade com os escritores de tragédias gregas" (Sat., $\mathrm{V}, 18,21)$. Obviamente, o nexo não deixou de ser explorado pelos estudiosos modernos, que se debruçaram sobre certas cenas e personagens mais específicos ou localizaram nele exatamente a particularidade da épica virgiliana. Mas, diante das diversas perspectivas, é preciso esclarecer o que se entende por tragédia na abordagem do poema de Virgílio.

\section{A tragédia e a $E_{\text {NEIDA }}$}

Embora a presença do elemento trágico na Eneida tenha sido notada desde a Antiguidade, foi a crítica do século XX que procurou desenvolvê-lo de modo mais consistente. Muito mais do que apontar os versos ou cenas das tragédias áticas que teriam inspirado Virgílio, a crítica pôs em evidência as situações e cenas de elaboração trágica que perpassam a épica do poeta mantuano. Sem que se cogite tratar de forma aprofundada as diversas interpretações que se erigiram sobre o filão trágico da Eneida, é importante salientar as linhas gerais do aproveitamento deste tema no poema virgiliano, a fim de que se evidencie a proposta de leitura a se realizar.

Nesse sentido, para lidar com o amplo conjunto de artigos e obras que se detiveram sobre o assunto, talvez seja proveitoso partir de algumas observações feitas por Philip Hardie em texto dedicado ao tema. Em "Virgil and tragedy", Hardie (2003, p. 312-4) identifica duas linhas de interpretação que empreenderam a ligação entre o poema de Virgílio e o drama grego do século $\mathrm{V}$ a.C. Uma delas é a proposta por Richard Heinze ainda no início do século XX, para tratar especialmente do enlace amoroso de Dido, rainha de Cartago, e Eneias. A outra, apontada de modo menos específico por Hardie, representaria uma tendência interpretativa mais ampla da crítica anglo-saxã (Hardie, 2003, p. 313), que partiria das ideias de Hegel sobre o trágico.

Invertendo-se a ordem seguida por Hardie, comece-se tratando dessa tendência hegeliana de leitura do trágico no tratamento da Eneida. Os pensamentos do filósofo alemão sobre a tragédia estão incluídos no contexto mais amplo dos seus Cursos de Estética, na parte em que trata da poesia, e mais especificamente da poesia dramática. Em seu entendimento, este tipo de poesia se define pelo embate ético entre os indivíduos representados, já que "constitui como ponto central as colisões de fins e de caracteres, bem como a dissolução necessária de uma tal luta” (Hegel, 2006, p. 235). A tragédia, como uma das espécies desse tipo de poesia, ao lado da comédia e do drama satírico, constrói-se como representação artística em que "os indivíduos se destroem por meio da uniteralidade de seu querer e seu caráter consistentes, ou devem resignados acolher em si mesmos aquilo contra o que eles 
mesmos se opuseram de modo substancial [...] (Hegel, 2006, p. 239-40). Para Hegel, é a Antígona, de Sófocles, com seu conflito entre Creonte e a protagonista que dá nome à peça que atualiza plenamente esse conceito de trágico como conflito ético.

Hardie (2003, p. 313) atribui a difusão desse conceito de trágico entre a crítica anglo-saxã a Andrew Cecil Bradley, com o artigo "Hegel's Theory of Tragedy", de 1909. Sugerindo talvez a longa duração dessa corrente, ele menciona como exemplares desse tipo de interpretação o Roman Poetry, escrito em 1923 por Edward E. Sikes, e o artigo de Rory B. Egan, "Euryalus' mother and Aeneid 9-12" sobre a mãe de Euríalo no livro 9 da Eneida, publicado em 1980.

Baste para o encaminhamento da questão uma breve referência ao texto de Sikes. Ora, analisando o perfil estoico do herói virgiliano, o autor nota como o compromisso de Eneias em atender o destino o coloca em rota de colisão com os interesses de Dido. Acolhido em Cartago pela rainha com quem se une, Eneias assume o papel que lhe atribuem os Fata e decide que deve deixar Dido, obviamente em detrimento da continuidade de seu relacionamento com ela. Citando o verso Italiam non sponte sequor - [Não vou por meu querer à Itália] (Eneida, IV, 361) -, Sikes repara que, embora o herói aja contra seu desejo, não deixa de aderir por vontade própria ao destino (Sikes, 1923, p. 189). Assim, ao comentar o livro IV, da Eneida, Sikes declara (1923, p. 190) que "o quarto livro é uma tragédia, e a essência da tragédia é um conflito, não apenas de vontades, mas de direitos. Ambos, Eneias e Dido, têm seus pontos de vista [...]".

Voltado à interpretação de Philip Hardie, caso o entendimento aqui proposto de suas ideias esteja correto, parece que podem ser incluídos nessa linhagem outros trabalhos - alguns dos quais, diga-se de passagem, de críticos não anglo-saxões - que exploram e ampliam o sentido da tragédia como contradição conforme proposto por Hegel. Sem qualquer pretensão de se apresentar uma lista completa e exaustiva, lembrem-se os artigos de Herbert H. Yeames, "The Tragedy of Dido I and II”, de 1913, em que o autor nota que "os elementos conflitantes de amor e dever, que são a essência dessa tragédia [entre Dido e Eneias], são ampliados pelo conflito entre nacionalidades representado por Eneias e Dido."; o trabalho de J. Swanepoel "Infelix Dido: Vergil and the notion of the tragic", de 1995, em que analisa a "culpa" da rainha de Cartago em seu relacionamento com Eneias, partindo do entendimento de que "o drama trágico clássico é usualmente caracterizado tanto por um conflito que acontece e chega a uma conclusão, quanto pela queda de uma grandiosa e típica figura", para afirmar que "o conflito na Eneida ocorre em diversos níveis" (Swanepoel, 1995, p. 33); por fim, o texto "The Strategy of Contradiction", de Gian Biagio Conte, em que sustenta que a Eneida "toma emprestada sua linguagem do drama [...] Virgílio estrategicamente construiu seu poema épico na forma de contradições” (Conte, 2007, p. 152).

De outra parte, a linha de interpretação que Philip Hardie julga ser representada por Richard Heinze remonta a Aristóteles. Embora o texto do Estagirita seja bastante conhecido, não custa rememorar alguns dos pontos pertinentes para o assunto de que trata este trabalho. Se Hegel fala da tragédia em termos de conflito, muitos séculos antes dele Aristóteles tratava do gênero tendo em vista as emoções que este tipo de obra pretende despertar. Para ele, a tragédia é um tipo de representação poética cujo propósito é suscitar temor e compaixão. 
Tendo em vista essa finalidade, formula sua teoria - ou preceptiva -, segundo a qual a tragédia mais bem acabada seria aquela em que se manifesta uma "reversão da fortuna [...] da prosperidade à adversidade, e que se dê não por maldade [da personagem], mas em função de um grande erro cometido pelo herói” (Aristóteles, Poética, 1453a).

Este é o sentido adotado por Richard Heinze, em seu Vergil's epische technik, ao tratar da construção artística do relacionamento de Eneias com a rainha Dido. No capítulo III, o crítico alemão demonstra como Virgílio elaborou aquele movimento em direção à infelicidade no caso da relação entre a rainha de Cartago e o herói peregrino. Sua análise mostra como o conjunto da representação é completamente articulado para dar sentido trágico à temática amorosa que, conforme nota, estaria, a rigor, vazada mais adequadamente no epyllion, gênero típico da poesia helenística, do que na épica. Sem que se possa comentar mais detidamente a distinção de Heinze entre épica e epyllion, ressalte-se que ela parece assentar-se sobretudo no âmbito do conteúdo. Nesse caso, épica significaria a épica heroica.

Para Heinze, Virgílio mostra ao leitor, desde o livro I, o interesse vigoroso de Dido por Eneias e dessa forma encaminha a representação para a proposição de um amor recíproco entre ambos. No entanto, o caráter trágico da situação se desenvolve a partir do senso de pudor de Dido, que, depois da morte de seu esposo, recusa outro matrimônio. A superação hesitante desse escrúpulo para a consumação do enlace com Eneias se mostra completamente desastrosa para ela quando, após um breve momento de convívio, o filho de Vênus revela sua intenção de partir. Então se concretiza a reversão da fortuna apontada por Aristóteles. Seja como for, a interpretação de Heinze dispensa outros conceitos lançados pelo Estagirita, como o de hamartía ou do páthos trágico para tratar do episódio. Mas, certamente, isso não é um demérito de Heinze, apenas revela a perspectiva de sua interpretação.

Hardie não cita outros textos para ilustrar mais profundamente a linha de interpretação que pensa a épica virgiliana eivada pela tragédia segundo a perspectiva aristotélica. Apesar disso, talvez não fosse equivocado incluir nesse conjunto ao menos dois textos. Um deles é o artigo "The Tragedy of Turnus", de J. B. Garstang, em que afirma de início que o "episódio de Turno em Virgílio é uma tragédia em sentido próprio” (1950, p. 47). Articulando conceitos aristotélicos como compaixão, temor, hamartía e peripécia, Garstang aponta que, ao longo da narrativa, Virgílio constrói uma representação do inimigo de Eneias em que se desperta a compaixão por Turno, devido ao fato de ele estar na trágica situação de ter de travar um combate, por motivos pessoais, familiares e sociais, que o levará à morte.

O outro é o artigo de J. L. Moles, "Aristotle and Dido's Hamartia", de 1984, em que se trata da questão da hamartía da rainha de Cartago. Moles entende que Dido corresponde à "figura trágica central do modelo aristotélico" (1984, p. 50), já que sua trajetória descreve um movimento da felicidade para a infelicidade. Analisando a culpa de Dido, argumenta que ela não reside no fato de a rainha ter se apaixonado por Eneias, mas em ter escolhido envolver-se com o herói.

Philip Hardie nota que a adoção do sentido hegeliano de tragédia como conflito entre o indivíduo e as forças contrapostas que permeiam sua existência encaminha as análises para o tratamento de uma personagem específica. Normalmente, elas focam nos elementos psicológicos e morais das situações. $\mathrm{Na}$ verdade, essa perece ser uma tendência igualmente 
verificável na linhagem aristotélica de interpretação da tragédia na Eneida. O procedimento mais comum é o tratamento de uma personagem específica e na maioria das vezes voltado para a análise da situação de Dido.

De todo modo, procurando escapar desse tipo de interpretação, Hardie pretende dirigir sua leitura para outra direção. Assim, alega, em lugar de se deter em uma personagem, ele se volta para as correlações socioculturais da realização poética de Virgílio. Para efetivar sua proposta, opera com as formulações de Jean-Pierre Vernant sobre a tragédia ática do século V a.C. Para o historiador francês, esta forma de representação artística surge do lapso da experiência social constituído no tecido social pela inscrição na vida das oposições "entre os pensamentos legal e político, de um lado, e as tradições míticas e heroicas, de outro" (Vernant; Vidal-Naquet, 1999, p. 4), isto é, entre uma forma de organização coletiva e a manutenção do heroismo individual.

Hardie inverte, todavia, o pensamento do autor francês para aproveitá-lo na interpretação do texto virgiliano, considerando as condições históricas em que surgiu. Assim, ao passo que na Grécia a tragédia estilizaria poeticamente os problemas causados pela manutenção do individualismo heroico numa sociedade cujas instituições se organizam cada vez mais pela coletividade, em Roma ocorreria o movimento contrário, com a emergência da individualidade projetando-se contra o quadro coletivo (Hardie, 2003, p. 317). Dessa forma, o termo "tragédia" indica a problematização artística de certos aspectos da realidade social.

Considerada dessa perspectiva, a Eneida seria permeada pelo trágico na medida em que algumas cenas mimetizariam as tensões sociais presentes no Império recém-implantado. Por exemplo, a morte de Turno por Eneias seria a estilização poética das questões relativas à postura violenta ou clemente do imperador. No mesmo sentido, o episódio com Marcelo no fim do livro VI põe em termos artísticos o risco que corre uma sociedade em que todo o tecido social e as estruturas de poder são dependentes de uma só figura (Hardie, 2003, p. 317-8).

Outros trechos são arrolados por Hardie para ilustrar o sentido de tragédia de que se serve, mas não é necessário continuar acompanhando seu texto. Registre-se que ideias semelhantes sobre a relação do trágico com a situação sociocultural em Roma aparecem em outros textos que não mencionam os trabalhos de Vernant e Vidal-Naquet. Com relação às associações entre o poema e a sociedade romana, mencione-se apenas que esta foi uma prática de larga repercussão no século XX. Sumariamente, seja dito que se formou certa oposição entre uma crítica de origem europeia, que concebia a Eneida como um épica eufórica a respeito da ordem proposta por Augusto, e a crítica norte-americana para quem o poema não é propriamente apologético, mas representa certas tensões do ambiente social romano do mesmo período.

No que tange à relação desse contexto com a presença da tragédia no texto, pode-se lembrar o artigo de Adam Parry, "The Two Voices of Virgil's 'Aeneid", de 1963, em que sugere no poema a existência de "uma voz pública de triunfo e outra privada, de tristeza (regret)" (Parry, 1963, p. 80) que se concretiza na situação trágica de Eneias, que "não pode ser um herói, estando a serviço de um poder impessoal" (p. 80). Mais recentemente, em Greek Tragedy and Vergil's Aeneid, Vassiliki Panoussi defende que o poeta "adota e manipula 
os conflitos e ambiguidades inerentes à tragédia grega para expressar ansiedades acerca da nova ordem político-social de Augusto.” (2009, p. 7).

Seja como for, mais importante é notar que as três posições aqui resumidas apontam para a presença do elemento trágico na Eneida não só em diferentes episódios do poema, como também em níveis artísticos distintos. Encaminhando-se nesse mesmo sentido, aqui interessa sobretudo acompanhar a construção da fuga como elemento do enredo épico.

Para tanto, parte-se da consideração aristotélica sobre o páthos trágico como componente instrumentalizado por Virgílio a fim de transformar a fuga em tema passível de figurar num poema épico. Ora, na Poética, 1453b, o Estagirita define a tragédia, entre outras coisas, pelos sentimentos que mobiliza: o temor, phóbos, e a compaixão, éleos. Neste mesmo passo, sobre este último sentimento, vale notar que Aristóteles percebe que a comoção, páthos, diante de um fato terrível não se desdobra necessariamente em compaixão. Para que assim se dê, é preciso que haja laços afetivos, familiares ou de amizade, entre as partes envolvidas nos eventos. No trecho, o filósofo parece ter em mente as relações entre as personagens da peça. A compaixão adviria de um ato terrível cometido por uma das partes contra a outra sem que tenham conhecimento de uma ligação profunda existente entre eles. No entanto, em trecho anterior, ao tratar da situação trágica, Aristóteles aponta que a compaixão "diz respeito ao [homem] que vive a adversidade sem a merecer" (Poética, 1453a). Entende-se que, na Eneida, Virgílio faz o herói representar sua situação exatamente a partir dessa perspectiva, como um homem que sofre sem o merecer e, a partir disso, evoca os sentimentos pertinentes ao seu relato à rainha Dido, para quem conta como se deu sua saída de Troia.

\section{A TRagédia da FUGA}

A dificuldade em se incorporar a fuga como temática épica heroica com a qual Virgílio teve que lidar não vinha somente da inadequação fundamental do motivo com o gênero cuja marca é relatar proezas heroicas. No caso específico da partida de Eneias, a tradição havia legado diferentes versões sobre os eventos relativos ao final da guerra de Troia e às andanças do herói. Essas variantes, de certo bem difundidas em Roma, apresentavam por vezes divergências em pontos importantes e nem sempre eram tão lisonjeiras para o herói.

Tito Lívio, por exemplo, relata no umbral de seu $A b$ Urbe Condita que o herói virgiliano teria sido poupado pelos aqueus porque sempre teria sido contrário à guerra e favorável à devolução de Helena a Menelau. Embora não se mencione nada que desabone a conduta de Eneias, o fato é que, neste relato, sua saída de Troia parece ter sido tranquila, sem grandes traumas e carente de gestos heroicos. Uma variante talvez menos gloriosa é a da Iliupersis, "O saque de Troia", epopeia do "ciclo troiano" escrita por volta do século VII a.C., cujo texto se perdeu. Segundo Proclo, gramático do século V (?) que fez um resumo do poema, Eneias teria decidido fugir de Troia assim que Laocoonte e seus filhos foram atacados pelas duas grandes serpentes surgidas do mar (Gatti, 2012, p. 143). Mais uma vez, a decisão é fruto do medo ou da prudência e não há qualquer heroísmo no gesto.

Em suas Antiquitates Romanae, Dionísio de Halicarnasso registra mais versões a respeito do comportamento de Eneias e da queda de Troia. Uma delas constava do Laocoonte 
de Sófocles, peça de que restaram apenas fragmentos. Nela, Eneias, seguindo ordens de seu pai, transfere sua casa para o Monte Ida antes da tomada da cidade (Dion. Hal., Ant. Rom., 1, 48). Aqui também não se nota qualquer feito memorável ou ato de bravura sua. Mas, entre os relatos coligidos por Dionísio, encontra-se uma versão efetivamente aviltante para o filho de Vênus e Anquises. Esta seria a de Menecrates de Xanto. Segundo ela, o filho de Anquises e Vênus teria traído seus compatriotas e entregado Troia aos aqueus, tendo sido poupado graças a isso (Dion. Hal., Ant. Rom., 1, 48). Nesse caso, em lugar do heroísmo e da bravura, figuram a traição e o oportunismo.

A versão de Virgílio, no entanto, é bem próxima à veiculada por Helânico, com a qual, aliás, o próprio Dionísio está de acordo. Helânico foi um historiador grego do século V a.C., que, em sua obra Troica, narrou eventos ligados à guerra de Troia. É ele que apresenta o relato mais favorável a Eneias. Assim, na noite da invasão grega, o herói virgiliano teria se retirado para a cidadela, levando consigo outros que desejavam fugir. Ao perceber que não haveria como resistir, teria decidido pela fuga, a fim de salvar os que o acompanharam, os objetos dos antepassados e o que houvesse de valor. Com tal finalidade, teria determinado que um pequeno destacamento acompanhasse as mulheres, as crianças, os idosos e todos os que tivessem alguma dificuldade para escapar para o monte Ida. Ele próprio, enquanto isso, com a parte mais valorosa da tropa, teria permanecido na cidadela dando combate aos inimigos, com o intuito de evitar que atacassem o grupo fugitivo.

Nesta versão, Eneias é representado como um guerreiro solidário, bravo e pio, características que Virgílio irá acentuar no poema, com a introdução de diferenças significativas. Por meio delas, ele alcança um andamento trágico, em que a ênfase recai sobre os sentimentos de dor e compaixão, conforme a caracterização aristotélica da tragédia. Para suscitá-los, Virgílio constrói o relato de Eneias em torno de quatro elementos, que, de acordo com a ordem do texto, são: a inserção da personagem Sinão; a pequena peripécia que se dá entre a comemoração pelos troianos da falsa partida dos gregos e a saída destes de dentro do cavalo de madeira; a tentativa de resistência de Eneias; e a inevitabilidade da destruição de Troia.

Mas, antes de se passar à análise desses pontos, é preciso chamar atenção para uma componente crucial na estruturação da versão criada na Eneida. À diferença do que ocorre nas outras variantes dos relatos sobre a guerra de Troia, a narrativa elaborada por Virgílio não é feita em terceira pessoa, mas pelo próprio Eneias. Em lugar do narrador épico, é um narrador-personagem que tomou parte nos acontecimentos quem dá sua versão dos fatos. Ora, embora o narrador épico incorpore a perspectiva do herói sobre a noite final e a fuga de Troia - basta lembrar que na introdução do poema o narrador chama Eneias de "fato profugus" -, deixar que o próprio Eneias conte os momentos finais da guerra e seu exílio abre espaço para uma manifestação mais intensa do páthos trágico. Eneias não é só uma testemunha ocular, mas alguém que vivenciou os eventos.

Como nota Richard Heinze, essa é uma novidade acrescentada por Virgílio. Os poetas trágicos, sobretudo Eurípides, quando lidaram com as lendas relativas à tomada de Troia já adotavam a perspectiva dos vencidos. É o que se vê, por exemplo, em peças como Hécuba ou Astroianas, de Eurípides, em que as mulheres prisioneiras se veem vulneráveis perante as 
atrocidades cometidas pelos vencedores. No entanto, não havia nenhuma versão da lenda em que os eventos fossem relatados de forma contínua por um troiano. No caso das peças, até por uma característica do gênero, os poetas "podiam retratar somente episódios individuais ou dar uma impressão geral da noite de terror. Mas Virgílio nos apresenta o relato, não de qualquer troiano, mas do pai do povo Romano." (Heinze, 1994, p. 3). Nos relatos de poemas posteriores sobre o assunto, como a Posthomerica, de Quinto de Esmirna, do século III e o Iliou álōsis, A Tomada de Ílion, de Trifiodoro, que provavelmente é do século V, a narrativa é feita sempre pelo narrador épico.

É verdade que o sentido primeiro da observação de Heinze no seu contexto original é, mais do que atentar para o ganho estilístico, ressaltar a dificuldade com que Virgílio teria que lidar ao tomar como herói uma figura que, sendo o ancestral de um povo tão conquistador como o romano, decidiu abandonar sua cidade e carregar os deuses para outro lugar. Concentrando-se, por assim dizer, no horizonte de expectativas do momento da criação da Eneida, Heinze entende que o problema de Virgílio é tornar a fuga aceitável para um povo combativo e crente na ligação íntima entre a cidade e as divindades. De seu ponto de vista, a Virgílio era preciso "evitar qualquer sentimento de vergonha, defender [...] sobretudo seu herói da acusação de covardia ou fraqueza, temeroso desânimo ou falta de lealdade com a pátria." (Heinze, 1994, p. 4).

Não há dúvidas de que as observações do crítico alemão são precisas. O que aqui se faz notar é que o deslocamento entre os narradores permite não só a satisfação dessas necessidades, como também torna certos expedientes da narrativa mais coerentes, porque partem de uma personagem emocionalmente envolvida com os acontecimentos. Certamente, o relato poderia ser feito pelo narrador épico, mas, tomando o caso em termos retóricopoéticos, se assim o fosse, a perspectiva desesperada, triste e melancólica talvez soasse despropositada. Passando a palavra a Eneias, Virgílio constrói poeticamente o relato de uma vítima da situação e, dessa forma, consegue um efeito mais harmônico e decoroso ao páthos trágico.

Desde o primeiro momento do relato está presente essa comoção triste, evocada por Eneias antes mesmo de passar aos fatos propriamente ditos. Ora, é com as seguintes palavras que o herói dispõe os ânimos de seus ouvintes:

Infandum, regina, iubes renouare dolorem,

Troianas ut opes et lamentabile regnum eruerint Danai, quaeque ipse miserrima uidi 5 et quorum pars magna fui. quis talia fando Myrmidonum Dolopumue aut duri miles Vlixi temperet a lacrimis? et iam nox umida caelo praecipitat suadentque cadentia sidera somnos. sed si tantus amor casus cognoscere nostros et breuiter Troiae supremum audire laborem, quamquam animus meminisse horret luctuque refugit, incipiam. 


\begin{abstract}
Mandas dor renovar indizível, rainha: as riquezas de Troia, o lúgubre reino, os dânaos devastaram; vi toda tristeza; nela tomei boa parte. Quem - isso narrando dos mirmidões ou dólopes, ou militar do duro Ulisses, não choraria? Já a noite vem do céu; e convidam ao sono as estrelas. Mas, se nossa desdita queres conhecer, algo ouvir da suprema batalha de Troia, com minha alma tremendo, do luto fugindo, começarei. ${ }^{1}$
\end{abstract}

(Eneida, II, 3-13)

Depois disso, o primeiro movimento de Eneias consiste em enfatizar o embuste dos gregos contra os troianos. O herói conta que, certo dia, os troianos viram os acampamentos gregos vazios e, não só pensando que o adversário tinha desistido da guerra, mas também tomados de curiosidade, deixaram os muros e se dirigiram ao lugar em que os inimigos se situavam. Ali, acharam o grande cavalo de madeira em que se esconderam os guerreiros que seriam transportados para dentro do muro junto com a enorme estátua. Admirados, os troianos discutiam sobre o destino a ser dado à obra: destruí-la ou levá-la para dentro da cidade. Entrementes, alguns jovens trazem um grego, chamado Sinão, que, embora a princípio tenha sido hostilizado, é por fim acolhido amistosamente pelos troianos. Ele se diz traído e abandonado pelos gregos, sem destino, sem esperança e assim é acolhido pelos seus antigos inimigos. Na verdade, tudo não passava de mentira forjada pelos gregos, sobretudo por Odisseu, que instruíra Sinão para que este, conseguindo a simpatia dos troianos, os convencesse de levar o cavalo para dentro dos muros. Ao fim e ao cabo, tudo se passa conforme os planos e por aí se principia a ruína dos troianos.

Eneias apresenta os gregos como adversários desleais, ardilosos, e se porta exatamente como alguém enganado, manifestando toda sua raiva e rancor contra os gregos. O herói se representa magoado e ressentido por ter sido ludibriado em sua boa-fé: não só ele, de fato, mas igualmente toda a cidade. Ora, a mágoa tem contornos trágicos já na Ilíada, com Aquiles e sua ira, e é elemento fundamental em peças como Prometeu Acorrentado, Electra e Édipo em Colono. A apropriação virgiliana desse mote, por sua vez, parece se servir da mesma perspectiva presente no Filoctetes. De fato, a peça de Sófocles se estrutura em torno do mesmo sentimento. A cena se passa em Lemnos e se organiza em torno de três personagens: Filoctetes, que havia sido deixado ferido naquela ilha pelos aqueus quando se dirigiam para Troia; Odisseu, um dos responsáveis pelo abandono de Filoctetes; e Neoptólemo, filho

\footnotetext{
${ }^{1}$ Embora existam boas traduções da Eneida em língua portuguesa - como as de Odorico Mendes, Carlos Alberto Nunes, Tassilo Orpheu Spalding e Agostinho da Silva, para mencionar apenas as traduções de circulação mais difundida atualmente - preferiu-se a tradução própria dos versos citados a fim de captar sentidos que, talvez por questões de coerência e estilo, foram deixados de lado em outras propostas.
} 
de Aquiles, que acompanha o marido de Penélope. O enredo é construído a partir de uma versão segundo a qual havia uma profecia que declarava que os gregos só conseguiriam tomar Troia caso levassem o herói desamparado com seu arco infalível para a cidade de Príamo. Para conseguir isso, Odisseu se serve do jovem Neoptólemo a fim de enganar Filoctetes e conduzi-lo com seu arco para Troia.

Ingênuo, Neoptólemo aceita a princípio participar do plano de Odisseu. Este, evitando se revelar imediatamente a Filoctetes, apenas instrui o jovem na maneira de mentir para alcançar seus objetivos. Tais são as orientações de Odisseu ao filho de Aquiles:
afirma que deixaste a esquadra acaia
sonhando com teu lar! Te rói a ira,
pois foram te buscar com litanias,
só assim - diziam - conquistariam Ílion,
mas na hora da partilha, dão as armas
do pés-velozes a quem de direito?
Que nada! Frios, premiam Odisseu.
Solta os cachorros contra mim, sem pejo, que eu não me ofendo! $[. . .]^{2}$

\section{(Filoctetes, 58-66)}

Com "na hora da partilha", o filho de Laertes se refere à entrega das armas de Aquiles a ele próprio depois da morte do herói. Neste trecho, no entanto, o ponto central é que Odisseu sugere que Neoptólemo crie um vínculo de confiança com Filoctetes, fingindo que teria sido igualmente prejudicado por ele próprio, Odisseu. É exatamente o que faz o jovem, mas ao longo da peça sua simpatia vai se dirigindo para a figura de Filoctetes. A fragilidade deste desperta a compaixão do filho de Aquiles, que acaba revelando seus planos e passa a apelar para a confiança recém-estabelecida. Por fim, embora o herói abandonado relute, Hércules intervém e lhe assegura não só que Neoptólemo é sincero, mas também que, indo a Troia, encontrará a cura para sua ferida.

Em ensaio sobre esta peça de Sófocles, Edmund Wilson sintetiza bem o caráter de Filoctetes e o veio explorado pelo dramaturgo grego. Segundo o crítico, "[Filoctetes] é um homem obcecado por uma mágoa que, no seu caso, a agonia de um tormento físico o impede de esquecer; e para Sófocles sua dor e ódio têm uma dignidade e um interesse." (Wilson, 2009, p. 198). E pensando essa tragédia em termos hegelianos, isto é, como conflito, o crítico ressalta ainda como o dramaturgo coloca em xeque a ética atualizada por Odisseu para a justificativa do engodo que planejara contra Filoctetes. Embora no final Odisseu alcance o que pretendia, isso não significa a recusa de legitimidade ao ponto de vista de Filoctetes. De fato, não é "evidente para ele [Sófocles] que a moralidade de Odisseu, que mente e rouba em nome da pátria, necessariamente mereça prevalecer sobre a animosidade do torturado Filoctetes." (Wilson, 2009, p. 198-9).

\footnotetext{
${ }^{2}$ Tradução de Trajano Vieira (2009)
} 
$\mathrm{Na}$ Eneida, Virgílio constrói o relato de Eneias de modo semelhante à representação na peça de Sófocles. Aqui, Odisseu, mais uma vez, é o responsável por arquitetar um plano nefasto, desta vez contra uma cidade inteira; no lugar de Filoctetes, se encontram os troianos, que serão enganados; Sinão, por sua vez, exerce papel semelhante ao de Neoptólemo, mas que, à diferença deste, não abdica de seu papel de velhaco. De fato, ele permanece mentindo até o final e aplica os expedientes ensinados por Odisseu. Dessa forma, para angariar a simpatia dos troianos e fazer com que coloquem o enorme cavalo de madeira na cidade, finge ter rompido com os gregos e ter-se tornado inimigo do marido de Penélope. Os troianos compadecidos o acolhem, e o adotam como um dos seus para sua própria infelicidade.

Com efeito, é a insistência de Eneias no papel que Sinão teria desempenhado na destruição de Troia que descortina a mágoa do herói. O papel de vilão que lhe é atribuído na Eneida não era ignorado em outras versões da lenda e em alguns casos, como o da Parva Ilias, "A Pequena Ilíada", teria ele sozinho engado os troianos (Heinze, 1994, p. 6). É verdade que Virgílio, de sua parte, junta o engano de Sinão ao prodígio das serpentes contra Laocoonte e seus filhos como causas da queda de Troia. No entanto, a presença de Sinão e sua atuação têm sobretudo a função de atrair a simpatia para os troianos, representando-os como vítimas de suas próprias virtudes exploradas por um inimigo cujos escrúpulos não conhecem limites. No trecho em que narra a chegada de Sinão, o herói manifesta perplexidade e intensifica o suspense sobre os planos dos gregos, a esta altura claramente definidos como vis.

Ecce manus iuuenem interea post terga reuinctum pastores magno ad regem clamore trahebant Dardanidae, qui se ignotum uenientibus ultro, hoc ipsum ut strueret Troiamque aperiret Achiuis, obtulerat, fidens animi atque in utrumque paratus, seu uersare dolos seu certae occumbere morti. undique uisendi studio Troiana iuuentus circumfusa ruit certantque inludere capto. accipe nunc Danaum insidias et crimine ab uno disce omnis.

Então, preso, de mãos amarradas às costas, em alvoroço, trazem os pastores um jovem, no mais, desconhecido dos que chegavam. A fim de ocasião criar, abrir Troia aos aqueus, se entregara, com fé em si, e preparado: ou perpetrar o dolo, ou morrer de certo. De toda parte, jovens troianos acorrem ânsia de ver - e brigam por zombar do preso. Dos dânaos nota só o ardil e deste crime Entende os outros.

(Eneida, II, 57-66) 
Eneias começa por mostrar Sinão completamente subjugado pelos troianos justamente para chamar atenção para a capacidade de ludibriar do prisioneiro. Embora indefeso, ainda assim ele foi capaz de induzir os troianos ao erro. Na sequência, o espião aplica contra os troianos os mesmos conselhos que Odisseu dá a Neoptólemo na peça de Sófocles: fala mal dos amigos e se finge indignado para conquistar a confiança dos inimigos. Nesse sentido, considerando o contexto mais amplo do trecho em que Eneias fala da proeza de Sinão, capaz de reverter uma situação que lhe era quase totalmente adversa, pode-se dizer que os versos 65 e 66, além da perplexidade que Eneias deseja despertar nos ouvintes - e não se deve perder de vista que está contando os eventos da queda de Troia para a rainha Dido -, revelam a profunda mágoa e arrependimento do herói e dos troianos.

Nesse sentido, no que tange ao páthos, o relato de Eneias é muito mais trágico do que a peça de Sófocles. Do modo como ele narra, a ruína que advém aos troianos graças às mentiras de Sinão é total e, alcançada injustamente, mais passível de gerar temor e compaixão. Neste caso, o engodo tem um desdobramento efetivamente aniquilador. Enquanto Neoptólemo não leva sua mentira até as últimas consequências, e Filoctetes encontra, no filho de Aquiles, alguém que entende e partilha de seu ponto de vista sobre as dores físicas e morais de que padece, Eneias e os troianos são afetados da maneira mais intensa pelas trapaças de Sinão. Nada lhes sobra, a não ser destruição e ruína.

Essa impressão é ainda intensificada pela pequena peripécia que se dá entre a introdução do cavalo e a revelação de seu conteúdo. Já se lembrou a formulação de Aristóteles segundo a qual o melhor tipo de tragédia é aquele em que se passa da felicidade para a infelicidade. Ora, esse é exatamente o tipo de experiência pela qual passam os troianos. A princípio felizes por pensarem que os inimigos estavam longe, são cruelmente pegos de surpresa por eles. A alegria é de fato a causa da ruína. Os festejos que levam os defensores de Troia ao cansaço ou à embriaguez aparecem em todas as versões sobre a tomada da cidade de Príamo, mas na épica de Virgílio está intimamente relacionada à credulidade e boa-vontade dos troianos em oposição à crueldade e falsidade dos gregos. Além do mais, ela representa a ingenuidade e a inadvertência de quem está prestes a padecer por uma grande adversidade, mas que ainda não consegue divisá-la, de quem está assumido uma posição de vítima sem o perceber. Este movimento narrativo ajuda a suscitar o páthos trágico.

É novamente o deslocamento da função de narrador que confere contornos mais intensos à cena. Segundo seu relato, Eneias não teria visto os gregos saírem de seu esconderijo. Ao contrário, foi surpreendido quando os estragos feitos pelos inimigos eram irreversíveis. Em verdade, teria sido acordado pelo fantasma de Heitor, que lhe aparecera em sonho para avisar da destruição que se lançava sobre Troia. Diante da imagem decrépita do filho de Príamo, Eneias tenta encetar uma conversa, mas Heitor é direto e manda-o fugir imediatamente: 
'heu fuge, nate dea, teque his' ait 'eripe flammis:

hostis habet muros, ruit alto a culmine Troia.

sat patriae Priamoque datum: si Pergama dextra

defendi possent, etiam hac defensa fuissent.

sacra suosque tibi commendat Troia penatis:

hos cape fatorum comites, his moenia quaere

magna, pererrato statues quae denique ponto.'

"Foge, filho de Vênus, salva-te das chamas!",

disse. "Os gregos tomam os muros, cai Troia.

Por Ílion e por Príamo, fez-se de tudo.

Tivessem salvação, minha mão a alcançara.

A ti confia Troia seus sacros objetos,

seus Penates: teus sócios leva, muros busca

para eles, que erguerás tendo cruzado o mar."

(Eneida, II, 289-95)

A aflição na fala de Heitor reflete não só o saque violento a que a cidade está sendo submetida, mas ressalta o risco que o próprio Eneias corre inadvertidamente. Acordado, o herói capta rapidamente o que está se passando, a armadilha em que caíram os troianos. Perturbado pela destruição, esquece-se da orientação dada pelo filho de Príamo para que fugisse.

Ora, já se mencionou como este ponto é controverso nas lendas. Em termos de criação artística, Virgílio lidava com uma personagem difícil de conformar aos modelos heroicos estabelecidos ou consolidados desde Homero. Além de a tradição historiográfica apresentar muitas versões desabonadoras da conduta do herói durante a ruína de Troia, a tradição poética não guarda registros de proezas do herói virgiliano. Já ficou dito que, no canto XX da Ilíada, por exemplo, Aquiles escarnece de Eneias justamente por tê-lo afugentado em uma batalha (v. 177-98). Por outro lado, como nota Aristóteles (Poética, 1453a), a compaixão trágica depende de que a personagem que sofre seja considerada um pouco melhor do que a maioria. Na Ética a Nicômaco, o Estagirita coloca justamente o medo excessivo como condição aviltante, especialmente para quem deve ser bravo. Este escolhe e enfrenta situações difíceis ou porque seja nobre fazê-lo, ou porque seja vergonhoso não o fazer" (E.N. 1116a). Neste caso, a fuga imediata não seria capaz de despertar a compaixão necessária para dar dignidade à figura de Eneias. Diante do impasse em que se encontrava, restou a Virgílio insistir no impulso de Eneias em defender a cidade, ainda que reconheça a inutilidade do gesto. É o que se lê nos versos abaixo:

[...] iuuenes, fortissima frustra pectora, si uobis audentem extrema cupido certa sequi, quae sit rebus fortuna uidetis. excessere omnes adytis arisque relictis di quibus imperium hoc steterat; succurritis urbi incensae: moriamur et in media arma ruamus. una salus uictis nullam sperare salutem. 
[...] Jovens, em vão valentes

corações, se de fato desejam seguir

um destemido, vede bem qual seja o caso:

Quedam abandonados altares e templos

dos deuses protetores. A cidade em chamas

socorreis: pereçamos em meio à batalha!

Não querer salvação é nossa salvação!

(Eneida, II, 348-54)

Ao comentar essa passagem, Maurice Bowra observa que a resistência de Eneias e dos troianos está mais próxima da coragem do desespero do que do autêntico espírito de heroísmo (Bowra, 1944, p. 42). Eneias não pensa em realizar grandes feitos individuais, mas se associa plenamente à cidade. No âmbito do poema, Virgílio faz Eneias demonstrar bravura e destemor, pois isso é necessário para angariar a simpatia dos seus ouvintes; no âmbito da recepção, Virgílio precisa atribuir algo do heroísmo tradicional a seu protagonista para lhe conferir heroísmo. Mais uma vez, cabe notar como o deslocamento de narrador contribui para a construção do texto. Em comparação com as outras versões da lenda, o relato do herói na Eneida aparece como uma espécie de autodefesa de suas virtudes guerreiras.

Por fim, resta falar da inevitabilidade da destruição de Troia. As lendas sobre a guerra entre gregos e troianos preveem que aos primeiros cabe o sucesso final. Esse é o elemento profético mais geral por trás da guerra e das versões que se criaram: Troia há de expiar a ofensa pelos erros de Páris, sobretudo o de ter participado da eleição entre Hera, Atena e Afrodite. No geral, Virgílio dá uma leve inflexão à lenda para construir sua épica, mas não lhe altera propriamente o teor. Seguindo os prenúncios constantes da Ilíada, XX, 307-8, e do Hino homérico 5, a Afrodite, que dizem que Eneias haveria de reinar sobre Troia, Virgílio, embora destrua esta cidade, faz com que os deuses dela sejam instalados por Eneias em outro lugar.

Seja como for, lembre-se que a tragédia ática explorou intensamente a atuação do fado na vida de algumas personagens. Peças como as Traquínias ou Édipo Rei são emblemáticas dos inescapáveis efeitos avassaladores do destino. Nelas, tanto Héracles como Édipo estão fadados ao sofrimento. Ainda que saibam de sua sina, o fato é que não percebem que estão enredados em circunstâncias catastróficas. Nestes casos, o momento de reconhecimento da desgraça é marcado por certa perplexidade. Héracles, ao ser ferido pelo manto de Dejanira, e Édipo, ao se descobrir filho de Laio, manifestam essa perturbação que intensifica o páthos trágico. A ocasião da clarividência costuma ser também a do aniquilamento.

$\mathrm{Na}$ Eneida, o herói cita amiúde o papel da fortuna na destruição de Troia. Aliás, o fado e os deuses são referidos desde o início da sua narrativa. Entre todas as menções, merece atenção especial a cena em que Vênus lhe revela a participação dos deuses na devastação da cidade. A se acreditar nos versos 567-88, que, segundo Sérvio, teriam sido retirados do poema, o herói está furioso, pois acabara de avistar Helena, por quem os gregos tinham movido a guerra, e se dirige para matá-la. A fim de conter e consolar Eneias, Vênus lhe descortina a atuação dos deuses na queda da cidade. É o que registram os versos seguintes: 
non tibi Tyndaridis facies inuisa Lacaenae culpatusue Paris, diuum inclementia, diuum has euertit opes sternitque a culmine Troiam. aspice (namque omnem, quae nunc obducta tuenti mortalis hebetat uisus tibi et umida circum caligat, nubem eripiam; tu ne qua parentis iussa time neu praeceptis parere recusa):

Que Helena, a espartana, não te avexe, Páris tampouco. É o poder, a inclemência divina que produz tudo isso, que subjuga Troia. Vê, pois retiro o véu que te impede a visão e teus olhos mortais embaça; não receies as ordens de tua mãe, nem lhes desobedeças.

(Eneida, II, 601-7)

Na sequência, Eneias explica sua visão de Júpiter, Netuno, Minerva e Juno destruindo a cidade. À diferença do que se passa nas tragédias, a cena da épica de Virgílio não apresenta o sentimento de perplexidade que intensifica o páthos trágico. Seja como for, a revelação de Vênus é o momento em que o herói se convence - e tenta convencer seus ouvintes - de que a ruína de Troia é inevitável. Os indícios anteriores, como a dificuldade em se colocar o cavalo dentro dos muros ou a própria aparição de Heitor em sonhos, não haviam sido suficientes para convencer Eneias. Em seu conjunto, ela é menos patética, porque a carga emocional inserida no contexto representa mais uma espécie de consolo do que incrementa a crise de Eneias. De todo modo, o núcleo da cena guarda a dimensão trágica da fatalidade, no sentido de que se constrói a partir da impotência do herói em deter os acontecimentos que presencia e que vão, em seu caso, lançá-lo na desgraça e no exílio.

\section{CoNClusão}

Embora, a princípio, seja um tema pouco conveniente para o tratamento épico, na Eneida Virgílio empresta à fuga uma dignidade condizente a este gênero poético. Para tanto, ele se serve de expedientes típicos da representação trágica com vistas a despertar o páthos deste tipo de poesia. Assim, em lugar de ser sinal de covardia ou mero sinal de derrota, a fuga se torna o resultado inescapável de uma série de fatores com que o herói tem de lidar. A perfídia incomum do inimigo e a determinação divina são a causa da destruição da cidade, contra a qual não há como lutar. Neste sentido, a alegria breve surgida entre os troianos graças à mentira dos gregos e a tentativa de Eneias de salvar a cidade tornam-se ingenuidade e bravura trágicas, uma vez que representam e despertam funestas dor e compaixão. É por meio desses expedientes que Virgílio consegue resolver o problema artístico com que tinha de lidar e integrar a fuga no conjunto de assuntos sérios e elevados. 


\section{REFERÊNCIAS}

ARISTÓTELES. Ética a Nicômaco. Brasília: Editora da UnB, 1999.

ARISTÓTELES. Poética. Tradução de Paulo Pinheiro. São Paulo: Editora 34, 2015.

BLÄNSDORF, J. Fragmenta Poetarum Latinorum Epicorum et Lyricorum: praeter Enni Annales et Ciceronis Germanique Aratea. Berlin: Walter de Gruyter, 2011.

BOWRA, C. M. From Virgil to Milton. London: MacMillian, 1961.

CONTE, G. B. The Strategy of Contradiction. In . The poetry of pathos. Oxford: Oxford University Press, 2007, p. 150-69.

DIONYSIUS OF HALICARNASSUS. Roman Antiquities. Cambridge, MA: Harvard University Press, 1937. v. 1.

GARSTANG, J. B. The Tragedy of Turnus. Phoenix, v. 4, n. 2, p. 47-58, 1950.

GATTI, I. F. A Crestomatia de Proclo: tradução integral, notas e estudos da composição do códice 239 da Bibliotheca de Fócio. 2012. 155f. Dissertação (Mestrado em Letras Clássicas) - Faculdade de Filosofia, Letras e Ciências Humanas da USP. São Paulo, 2012.

HARDIE, P. Virgil and tragedy. In MARTINDALE, C. The Cambridge Companion to Virgil. Cambridge: Cambridge Univesity Press, 2003, p. 312-326.

HEGEL, G. W. F. Cursos de Estética. São Paulo: Edusp, 2006. v. 4.

HEINZE, R. Virgil's Epic technique. Berkeley: University of California Press, 1994.

HOMERO. Ilíada. Tradução de Haroldo de Campos. São Paulo: Arx, 2002.

LIVY. History of Rome: books 1-2. Cambridge, MA: Harvard University Press, 1919. v. 1.

MACROBIUS. Opera. Stutgardiae: Teubner, 1994.

MOLES, J. L. Aristotle and Dido's Hamartia. Greece \& Rome, v. 31, p. 48-54, April 1984.

PANOUSSI, V. Greek Tragedy in Vergil's "Aeneid": ritual, empire, and intertext. Cambridge: Cambridge University Press, 2014.

PARRY, A. The Two Voices of Virgil's “Aeneid”. Arion, v. 2 n. 4, p. 66-80, Winter, 1963.

P. VERGILIUS MARO. Aeneis. Berlin: Walter de Gruyter, 2005.

SCHÖNBERGER, O. Quintus Ennius Fragmente (Auswabl). Stuttgart: Reclam, 2009.

SIKES, E. E. Roman Poetry. London: Methuen, 1923.

SÓFOCLES. Filoctetes. Tradução de Trajano Vieira. São Paulo: Editora 34, 2009.

SWANEPOEL, J. Infelix Dido: Vergil and the Notion of the Tragic. Akroterion, v. 40, p. 3046, 1995. 
VERNANT, J.-P.; VIDAL-NAQUET, P. Mito e Tragédia na Grécia Antiga. São Paulo: Perspectiva, 1999.

WILSON, E. Filoctetes: a ferida e o arco. In SÓFOCLES. Filoctetes. Tradução de Trajano Vieira. São Paulo: Editora 34, 2009, p. 193-213.

YEAMES, H. H. The Tragedy of Dido. Part I. The Classical Journal, v. 8, n. 4, p. 139-150, Jan. 1913. 